\section{Uncertain CERN cash means UK physicists face grant freeze}

London. University astronomers and physicists funded by Britain's Particle Physics and Astronomy Research Council (PPARC) have been told that no research grants will be made available to them in the next round of awards, due to start on 1 October, except in cases of "essential continuity or genuine hardship".

This decision, announced in a letter sent by the council to university research departments, reflects the uncertainty that is hanging over the funding agency about the extent to which the government will be prepared to meet the additional costs of Britain's membership of the European Laboratory for Particle Physics (CERN).

In particular, PPARC is seeking an extra 'pulse' of about $£ 60$ million (US\$90 million) over eight years, on top of its current budget, to help cover its contribution to the construction costs of the laboratory's Large Hadron Collider (LHC) (see Nature 381, 102; 1996). But the government's response is unlikely to be known until early next year, and research council officials have therefore decided to hold back any further research awards until the next round, in April 1997.

Although the decision will not affect the contributions that have already been agreed to major astronomy projects, both national and international, it will have a significant impact on the funding of smaller university-based projects. "This means that all the bright new ideas that we have are not going to be funded," says Malcolm Longair, Jacksonian Professor of Natural Philosophy at the University of Cambridge and president of the Royal Astronomy Society. "It's the seed-corn for the future that gets stifled on these occasions; that is where it really hurts."

PPARC officials say that, given the uncertainties over future commitments to CERN, they are choosing to exercise "a great deal of caution" over research awards. They are aware of a previous crisis that hit the research council's predecessor, the Science and Engineering Research Council, when excessive commitments based on an expectation of extra government funds that never materialized - was partly blamed for the early closure of the Nuclear Structure Facility at Daresbury.

PPARC has also decided to hold back new four-year rolling grants to universitybased particle physics groups. In the past, these have been renewed every two years; this time, researchers' salaries will be guaranteed at present only for a further two years, while funds for operating costs will be extended only for a further year, and at 70 per cent of last year's level.

\title{
Tribal groups attack ethics of genome diversity project
}

Washington. Citizens' groups in the United States and representatives of tribal peoples in poor countries this week attacked proposals for the Human Genome Diversity Project, which plans to collect systematically and make available for research genetic information about people from different ethnic groups.

The critics told a panel of the National Research Council (NRC), chaired by William Schull of the University of Texas at Houston, that the proposal should be suspended on ethical grounds. "We're not interested in the patenting and commercialization of our genes, so we're against it," said Leonor Zalabata Torres of Sierra Nevada in northern Columbia.

Torres was one of the representatives of the Arhuaco people who came to Washington on Monday to testify before the panel. They alleged that scientists had already taken thousands of samples from tribal people in Columbia without meaningful informed consent, and without consulting with tribal leaders (see Nature 381, 11-14; 1996).

According to Abadio Green Stocel, president of the National Indigenous Peoples' Organisation of Columbia, the samples had been given on the basis that they would be used "to analyse the health of the communities". They ended up, however, in gene banks at the Centre for Disease Control and the National Institutes of Health (NIH) in the United States.
The NRC panel had been asked by the National Science Foundation (NSF) and the $\mathrm{NIH}$ to look at various proposals that exist to bring together research in this field under a Human Genome Diversity Project. The NSF is currently inviting grant proposals for similar research under a small pilot programme. If the NRC panel finds that a larger, more systematic programme is justified, the NSF and NIH are likely to take its advice and move to establish one.

The NRC panel will examine the case for such a project and the difficulties in setting it up. It may also estimate its likely cost and duration. Eric Fischer, head of biology at the NRC and director of this study, says ethical concerns, such as ensuring informed consent, are "a substantial aspect" of the study.

Proposals under consideration include a summary prepared by the Human Genome Organization, the international genome group, and output from scientific workshops held at Stanford University in California in 1992 and in Sardinia, Italy, in 1993.

John Moore, a Seattle businessman who was involved in lengthy and ultimately unsuccessful court action after his genes were patented by the University of California at Los Angeles, the Genetics Institute and Sandoz, the Swiss pharmaceuticals company, also testified against the proposed project, saying that gene patenting had left him "violated as a human being".

Colin Macilwain

\section{First plant genome sequencing planned}

Washington. Four US federal agencies are about to announce an international effort to decode the genetic material of the fast-growing plant Arabidopsis thaliana - known as 'laboratory cress' - in a move that represents the first complete sequencing of a plant genome.

The National Science Foundation (NSF) will lead the US contribution to the three-year sequencing effort, which will also involve the US Agriculture Department (USDA) and the National Institutes of Health (NIH). The project will be carried out in collaboration with Japan's Kazusa DNA Institute in Chiba Prefecture, east of Tokyo, and a consortium of 17 European laboratories funded through the European Commission.

According to officials in Washington, the NSF will provide \$9 million for the US portion of the effort, with DoE's basic energy sciences unit contributing \$2.1 million and USDA another \$1.5 million. $\mathrm{NIH}$ will contribute its expertise in genome sequencing, but no funding.

Information from the sequencing is expected to be used to engineer plants to produce substances ranging from vaccines to chemicals and plastics. As well as boosting understanding of grain development, the project will lead to improvements in bioremediation.

The latter is an area of particular interest to $\mathrm{DoE}$, in view of the huge clean-up tasks it faces around nuclear facilities. The energy department is also interested in the project's implications for the growing use of biomass for energy production. The project is expected to take six years to complete.

In addition to being a rapid grower, with a seed-to-seed cycle that can be as short as three weeks, Arabidopsis also has the smallest genome size of any plant, comprising of only 100 million base pairs, or 100 megabases. By comparison, the human genome consists of 3 billion base pairs.
David Kramer 